\title{
Pengaruh Daun Binahong (Anredera cordifolia Steenis) terhadap Kadar Kolesterol Darah Tikus Wistar (Rattus norvegicus) Hiperkolesterolemia
}

\author{
Yanfrin Taslim', Anna Maria Dewajanti' ${ }^{2}$ Agus Limanto $^{2}$ \\ ${ }^{1}$ Fakultas Kedokteran dan Ilmu Kesehatan, Universitas Kristen Krida Wacana, Jakarta, Indonesia \\ ${ }^{2}$ Departemen Biokimia Fakultas Kedokteran dan Ilmu Kesehatan, Universitas Kristen Krida \\ Wacana, Jakarta, Indonesia \\ Alamat Korespondensi: anna.dewajanthi@ukrida.ac.id
}

\begin{abstract}
Abstrak
Aterosklerosis adalah penyakit kardiovaskuler yang menempati urutan pertama penyebab mortalitas dan morbiditas global. Penyakit ini ditandai dengan perubahan pada dinding pembuluh darah arteri yaitu terjadi penebalan dan kekakuan. Salah satu faktor penyebab terjadinya aterosklerosis adalah mengonsumsi makanan berlemak dan tinggi kolesterol. Daun Binahong (Anredera cordifolia (Ten.)Steenis) dipercaya oleh masyarakat dapat menurunkan kadar kolesterol. Untuk mendapatkan zat dan bahan aktifnya maka daun binahong dibuat dalam bentuk ekstrak. Pada penelitian ini daun binahong diekstrak dalam etanol $96 \%$ dan untuk pengukuran kadar kolesterol total digunakan easy touch GCU. Penelitian ini menggunakan tikus putih (Rattus norvegicus). Tikus dibagi menjadi 4 kelompok yaitu kelompok hiperkolesterolemia tanpa perlakuan (kontrol), kelompok hiperkolesterolemia dengan pemberian simvastatin (kontrol positif), kelompok hiperkolesterolemia dengan pemberian ekstrak daun binahong $(1000 \mathrm{mg} / \mathrm{kgBB}$ dan $1500 \mathrm{mg} / \mathrm{kgBB})$. Kesimpulan berdasarkan hasil penelitian menunjukkan bahwa ekstrak daun binahong 1000 dan $1500 \mathrm{mg} / \mathrm{kgBB}$ dapat menurunkan kadar kolesterol darah. Hasil uji statistik bahwa pemberian ekstrak daun binahong $1000 \mathrm{mg} / \mathrm{kgbb}$ memiliki efek dalam penurunan kadar kolesterol total darah secara signifikan pada hari ke-14.
\end{abstract}

Kata Kunci: Anredera cordifolia (Ten.) Steenis, hiperkolesterolemia, Rattus norvegicus

\section{The Effect of Binahong Leaf (Anredera cordifolia Steenis) on Blood Cholesterol Level of Wistar Rat (Rattus norvegicus) Hypercholesterolemia}

\begin{abstract}
Atherosclerosis is a cardiovascular disease that ranks first as a cause of global mortality and morbidity. This disease is characterized by changes in the walls of the arteries including thickening and stiffness of the arteries. One of the factors that cause atherosclerosis is consuming food with high content of fat and cholesterol. Binahong is traditonally used for the treatment of high cholesterol. To get the active ingredients, the leaves of binahong must be made in extract form. In this study, binahong leaf extract was made in $96 \%$ ethanol. Measurement of total cholesterol levels using easy touch GCU. This study used white rats (Rattus norvegicus) as experimental animals. Rats were divided into 4 groups: Group 1 was hypercholesterol mice with no treatment, group 2 was hypercholesterol mice with simvastatin administration, group 3 was hypercholesterol mice with $1.000 \mathrm{mg} / \mathrm{kg}$ binahong leaf extract and group 4 was hypercholesterol mice with $1.500 \mathrm{mg} / \mathrm{kg}$ binahong leaf extracts. The results showed that binahong leaf extract $1.000 \mathrm{mg} / \mathrm{kg} \mathrm{bw}$ and 1.500 $m g / k g b w$ could lower blood cholesterol levels. From the results of statistical tests, the administration of extracts of binahong leaves $1.000 \mathrm{mg} / \mathrm{kg}$ has an effect in reducing blood cholesterol levels on the 14 day.
\end{abstract}

Keywords : Binahong (Anredera cordifolia (Ten.) Steenis), Hypercholesterolemia, Rattus norvegicus 


\section{Pendahuluan}

Aterosklerosis adalah penyakit kardiovaskuler (penyakit jantung dan pembuluh darah) yang merupakan salah satu penyumbang angka mortalitas dan morbiditas. Menurut WHO 2020, setiap tahunnya diperkirakan 17 juta orang meninggal akibat penyakit kardiovaskuler terutama akibat serangan jantung dan stroke. ${ }^{1}$ Penyakit kardiovaskuler juga merupakan salah satu penyakit yang menjadi perhatian khusus di Indonesia. Berdasarkan hasil Riskesdas 2013 menunjukkan bahwa prevalensi jantung koroner sebanyak $1,5 \%$, gagal jantung $0,3 \%$, dan prevalensi stroke sebanyak 57,9\%. ${ }^{2}$ Hasil Riskesdas 2018 menunjukkan prevalensi penyakit jantung di Banten pada semua umur sebesar $1,4 \%{ }^{3}$

Aterosklerosis ditandai dengan perubahan pada dinding pembuluh darah arteri yaitu terjadi penebalan dan kekakuan. ${ }^{4}$ Beberapa faktor risiko terjadinya aterosklerosis antara lain usia, jenis kelamin, keturunan (ras), merokok, tinggi kolesterol dalam darah, hipertensi, kurang aktivitas fisik, diabetes mellitus, obesitas dan berat badan lebih. $^{5}$

Dalam penatalaksanaan hiperkolesterol, langkah pertama yang harus dilakukan adalah penatalaksanaan tanpa obat berupa pengaturan pola makan (diet) dan aktivitas fisik. Apabila dengan langkah pertama ini tujuan penatalaksanaan belum tercapai dapat dikombinasikan dengan langkah farmakologis berupa obat penurun kolestrol (statin). Penatalaksanaan hiperkolestrol dengan terapi obat dapat menimbulkan masalah terkait obat (drug related problems) yang dialami oleh penderita yang berupa efek samping yang ditimbulkan oleh obat tersebut. Masalah terkait obat merupakan keadaan terjadinya ketidaksesuaian dalam pencapaian tujuan terapi sebagai akibat pemberian obat. $^{6}$

Dalam beberapa dekade terakhir, para peneliti mulai mengembangkan tanaman obat sebagai sumber antioksidan dan alternatif pengobatan kolesterol. Salah satu tanaman yang dapat dimanfaatkan sebagai obat tradisional untuk kolesterol adalah daun binahong (Anredera cordifolia/A. cordifolia). Tanaman binahong berasal dari dataran cina dengan nama dheng shan chi $^{7-9}$ di Eropa tanaman ini dinamai heartleaf madeiravine dan di Amerika Selatan dinamai madeira-vine. ${ }^{10}$ Di Indonesia, tanaman ini dikenal dengan nama gondola (Bali), kandula (Madura), uci-uci (Jawa). ${ }^{11}$ Hampir semua bagian tanaman binahong dapat digunakan dalam pengobatan herbal, namun pada umumnya yang sering dipakai adalah bagian daun. ${ }^{12}$

Anredera cordifolia merupakan salah satu tanaman obat yang dimiliki Indonesia dan berpotensi untuk dikembangkan menjadi bahan baku obat, karena tanaman ini sering digunakan masyarakat untuk mengobati berbagai penyakit selain kolesterol, analgetik, pembengkakan sendi, diare, dapat pula untuk mengobati luka bakar dan meningkatkan daya tahan tubuh. Penelitian terhadap ekstrak daun binahong ini bertujuan untuk membuktikan apakah ekstrak daun binahong dengan kadar 1000 dan $1500 \mathrm{mg} / \mathrm{kg}$ berat badan dapat menurunkan kadar kolesterol darah total dan membandingkan efek kerjanya dengan simvastatin. Penelitian ini diharapkan dapat menambah bukti ilmiah tentang efek daun binahong terhadap kadar kolesterol darah total. Untuk mengetahui efek daun binahong terhadap kadar kolesterol total, penelitian ini menggunakan hewan coba yang dibuat hiperkolesterolemia dengan diberikan pakan tinggi kolesterol. Penelitian efektivitas ekstrak daun binahong terhadap penurunan kadar kolesterol darah total pada tikus yang diberi pakan tinggi kolesterol belum banyak diteliti sebelumnya.

\section{Metodologi}

Penelitian ini merupakan penelitian eksperimental menggunakan metode pre dan post test with controlled group design. Hewan coba yang digunakan adalah tikus Rattus norvegicus strain Wistar, jantan, usia 10-12 minggu dengan berat antara 200 sampai 250 g. Tikus pada penelitian ini dibagi menjadi empat kelompok yaitu kelompok kontrol positif tanpa perlakuan, kelompok kontrol positif dengan pemberian simvastatin, kelompok yang diberikan ekstrak daun binahong $1000 \mathrm{mg} / \mathrm{kgBB}$ dan 1500 $\mathrm{mg} / \mathrm{kgBB}$.

Perhitungan besar sampel menggunakan rumus Frederer yaitu : (t-1) $(\mathrm{r}-1) \geq 15$ dimana $\mathrm{t}=$ banyak kelompok (4 kelompok) perlakuan dan $\mathrm{r}=$ jumlah sampel per kelompok. Jumlah sampel minimal yang diperlukan adalah 6 ekor tikus untuk setiap kelompok. Penelitian ini menggunakan 24 ekor tikus.

Penelitian ini telah lolos kaji etik dari Komisi Etik Penelitian Medis dan Kesehatan Fakultas Kedokteran Universitas Kristen Krida Wacana (UKRIDA) dengan Nomor 705/SLKEIM/UKKW/FKIK/KE/III/2019 


\section{Pembuatan Tikus Hiperkolesterol}

Pemeliharaan dan pemberian perlakuan hewan coba selama penelitian dan pemeriksaan sampel darah dilakukan di laboratorium hewan FKIK UKRIDA. Untuk membuat tikus hiperkolesterolemia diberikan pakan tinggi kolesterol dalam bentuk pellet sehari 2 kali sebanyak $50 \mathrm{~g} /$ hari selama 14 hari. Setelah tikus menjadi hiperkolesterolemia, tikus diberi pakan standar. Pakan standar berisikan protein, serat, dan abu. Pemberian pakan standar dilakukan selama proses pemberian ekstrak daun binahong dari hari ke-0 sampai hari ke-14. Pemberian pakan standar diberikan sehari dua kali dengan berat $50 \mathrm{~g} / \mathrm{hari}$. Tikus dikatakan hiperkolesterol bila kadar kolesterol darah > $54 \mathrm{mg} / \mathrm{dl} .{ }^{13}$

\section{Pengambilan Sampel darah}

Pengambilan sampel darah dilakukan dengan cara tikus dipuasakan selama 12 jam tidak diberikan makan tetapi tetap diberi air minum. Untuk pengambilan darah tikus, langkah pertama adalah ujung ekor tikus didesinfektan menggunakan alkohol 70\%, kemudian ujung ekor tikus tersebut digunting, tetesan darah pertama dibuang, dan tetesan darah berikutnya baru digunakan untuk pengukuran. ${ }^{14}$ Pengukuran kadar kolesterol dilakukan menggunakan alat EASY Touch GCU.

\section{Pembuatan Ekstrak Daun Binahong dengan Pelarut Etanol}

Bubuk daun binahong diperoleh dengan cara diblender hingga halus. Maserasi dilakukan dengan memasukkan $200 \mathrm{~g}$ bubuk ke dalam beker glass berisi etanol $96 \%$ sampai $1000 \mathrm{~mL}$. Setelah itu beker glass ditutup dan dibiarkan selama 5 hari. Hasil maserasi tersebut kemudian disaring, dan cairan filtrat dievaporasi untuk menguapkan etanol yang digunakan sebagai pelarut. Setelah dievaporasi hasil ekstrak tersebut kemudian ditimbang, dan disimpan di dalam kulkas dengan suhu $5^{\circ} \mathrm{C}$ agar tidak rusak, lama penyimpanan kurang lebih 1 minggu sebelum pemberian ekstrak tersebut dilakukan terhadap hewan coba.

\section{Pembuatan Larutan Simvastatin}

Tablet simvastatin $40 \quad \mathrm{mg}$ digerus, ditambahkan akuades dan suatu suspending agent -kaboksimetil selulosa (CMC) 0,5 \% (Berdasarkan tabel konversi perhitungan dosis Laurence \& Bacharach, 1964; konversi dosis untuk tikus : $0,018 \times 40 \mathrm{mg}=0,72 \mathrm{mg} / \mathrm{kgBB}$. Untuk tikus dengan berat $250 \mathrm{~g}=0,72 \times 1000 / 250=2,88 \mathrm{mg}$ )

\section{Analisis Data}

Data sampel yang diperoleh dianalisis dengan menggunakan program statistika SPSS versi 24 diuji dengan $t$-test berpasangan, wilcoxon, t-test tidak berpasangan dan Mann-Whitney.

\section{Hasil}

Ekstraksi daun binahong dengan metode maserasi dilakukan dengan menggunakan pelarut etanol $96 \%$ karena flavonoid yang terkandung dalam daun binahong bersifat polar, sehingga diperlukan pelarut yang polar untuk menarik flavonoid tersebut dari daun binahong. Hasil ekstraksi bubuk daun binahong seberat $1000 \mathrm{~g}$ diperoleh sebanyak 107,5 g ekstrak. Rendemen ekstrak yang diperoleh sebesar 10,75\%.

\section{Hasil Pengukuran Kadar Kolesterol Tikus}

Pada Gambar 1 dapat dilihat kadar kolesterol dalam darah pada masing-masing kelompok. Kelompok 1 adalah kelompok tikus tinggi kolesterol tanpa diberikan perlakuan, kelompok 2 adalah kelompok tikus tinggi kolesterol dengan pemberian terapi obat simvastatin terhadap tikus, kelompok 3 adalah kelompok tikus tinggi kolesterol dengan pemberian ekstrak binahong dosis $1000 \mathrm{mg} / \mathrm{kgBB}$ dan kelompok 4 adalah kelompok tikus tinggi kolesterol dengan pemberian ekstrak binahong dosis $1500 \mathrm{mg} / \mathrm{kgBB}$. 


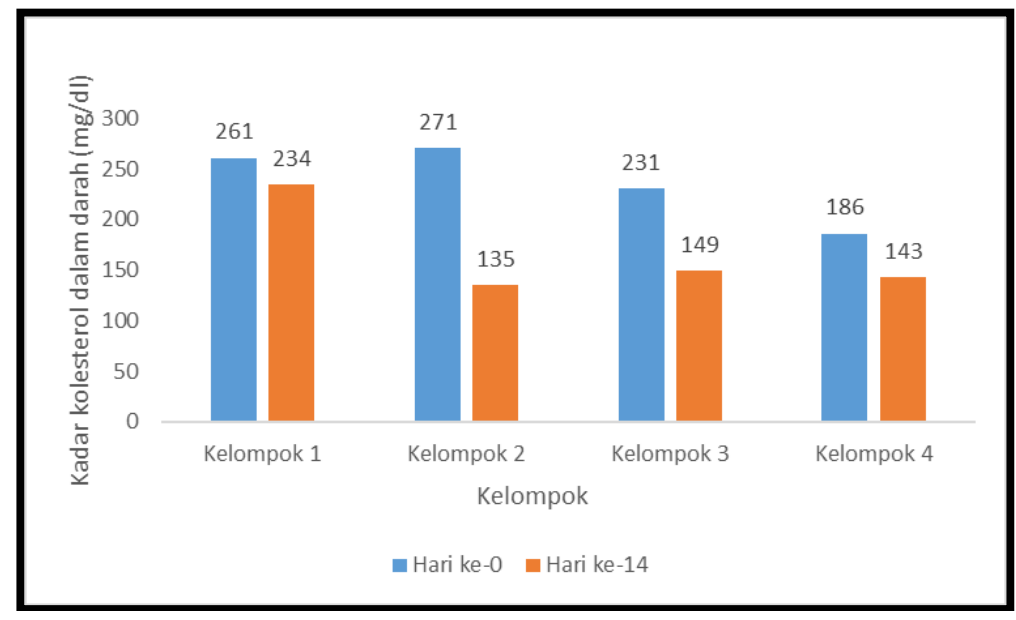

Gambar 1. Rata-rata Kadar Kolesterol Darah pada Setiap Kelompok (kelompok 1: kontrol, kelompok 2: simvastatin, kelompok 3: binahong $1000 \mathrm{mg} / \mathrm{kgBB}$, kelompok 4: binahong $1500 \mathrm{mg} / \mathrm{kgBB}$ )

Pada Gambar 2 dapat dilihat selisih kadar kolesterol dalam darah hari ke-14 dan hari ke-0 pada masing-masing kelompok. Kelompok tanpa diberikan perlakuan (kontrol) mengalami penurunan kadar kolesterol sebesar $27 \mathrm{mg} / \mathrm{dl}$, kelompok pemberian simvastatin mengalami penurunan kadar kolesterol sebesar $136 \mathrm{mg} / \mathrm{dl}$, kelompok pemberian ekstrak binahong dosis 1000 $\mathrm{mg} / \mathrm{kgBB}$ mengalami penurunan sebesar $82 \mathrm{mg} / \mathrm{dl}$ dan kelompok pemberian ekstrak binahong dosis $1500 \mathrm{mg} / \mathrm{kgBB}$ mengalami penurunan sebesar 43 $\mathrm{mg} / \mathrm{dl}$.

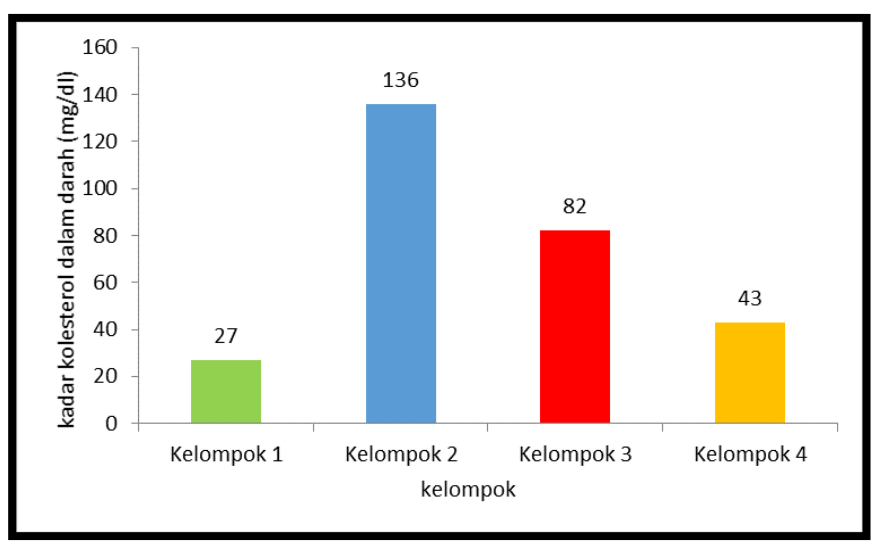

Gambar 2. Selisih Kadar Kolesterol Darah Hari ke-14 dan Hari ke-0 pada Masing-masing Kelompok (kelompok 1: kontrol, kelompok 2: simvastatin, kelompok 3: binahong $1000 \mathrm{mg} / \mathrm{kgBB}$, kelompok 4: binahong $1500 \mathrm{mg} / \mathrm{kgBB}$ )

Untuk mengetahui apakah ada perbedaan yang signifikan antara data rata-rata kadar kolesterol pada hari ke-0 dengan hari ke-14 pada masingmasing kelompok maka digunakan uji statistik.

Untuk mengetahui apakah ada perbedaan yang signifikan antara data rata-rata kadar kolesterol pada hari ke 0 dengan hari ke-14 pada kelompok 1 maka dilakukan uji normalitas dengan menggunakan Shapiro-wilk. Dari uji tersebut sebaran data kadar kolesterol total darah hari ke-0, nilai $\mathrm{p}=0,301$ dan hari ke-14, nilai $\mathrm{p}=0,334$; data berdistribusi normal bila nilai $\mathrm{p}>0,05$. Oleh karena data penelitian pada kelompok tikus hiperkolesterol tanpa diberi perlakuan berdistribusi normal, maka untuk menganalisis adanya perbedaan dan rata-rata kadar kolesterol darah pada hari ke-0 dan hari ke-14 dilakukan uji $\mathrm{T}$ berpasangan. Dari hasil uji $\mathrm{T}$ berpasangan didapatkan hasil $\mathrm{p}=0,697$, oleh karena nilai $\mathrm{p}>$ 0,05 maka dapat diambil kesimpulan bahwa tidak terdapat perbedaan data rata-rata kadar kolesterol 
darah pada hari ke-0 dan hari ke-14 pada kelompok tikus hiperkolesterol tanpa diberi perlakuan.

Untuk mengetahui apakah ada perbedaan yang signifikan antara data rata-rata kadar kolesterol pada hari ke-0 dengan hari ke-14 pada kelompok tikus hiperkolestrol dengan pemberian simvastatin, maka dilakukan uji normalitas dengan menggunakan Shapiro-wilk. Dari uji tersebut sebaran data rata-rata kadar kolesterol total darah hari ke- 0 , nilai $\mathrm{p}=0,825$ dan hari ke- 14 , nilai $\mathrm{p}=$ 0,039 ; data berdistribusi normal bila nilai $p>0,05$. Oleh karena sebaran data penelitian pada kelompok tikus hiperkolestrol dengan pemberian simvastatin tidak berdistribusi normal, maka untuk mengetahui adanya perbedaan data rata-rata kadar kolesterol darah pada hari ke-0 dan hari ke-14 dilakukan uji wilcoxon. Dari hasil uji wilcoxon didapatkan hasil nilai $\mathrm{p}=0,028$; oleh karena nilai $\mathrm{p}<0,05$, maka dapat diambil kesimpulan bahwa terdapat perbedaan data rata-rata kadar kolesterol darah pada hari ke-0 dan hari ke-14 pada kelompok tikus hiperkolestrol dengan pemberian simvastatin.

Untuk mengetahui apakah ada perbedaan yang signifikan antara data rata-rata kadar kolesterol pada hari ke-0 dengan hari ke-14 pada kelompok tikus hiperkolesterol dengan pemberian ekstrak daun binahong $1000 \mathrm{mg} / \mathrm{kgBB}$, maka dilakukan uji normalitas dengan menggunakan Shapiro-wilk. Dari uji tersebut sebaran data rata-rata kadar kolesterol total darah hari ke- 0 , nilai $\mathrm{p}=0,723$ dan hari ke-14, nilai $\mathrm{p}=0,782$; data berdistribusi normal bila nilai $\mathrm{p}>0,05$. Oleh karena data penelitian pada kelompok tikus hiperkolesterol dengan pemberian ekstrak daun binahong 1000 $\mathrm{mg} / \mathrm{kgBB}$ berdistribusi normal maka untuk menganalisis adanya perbedaan dan rata-rata kadar kolesterol darah pada hari ke-0 dan hari ke-14 dilakukan uji $\mathrm{T}$ berpasangan. Dari hasil uji $\mathrm{T}$ berpasangan didapatkan hasil nilai $p=0,034$. Oleh karena nilai $\mathrm{p}<0,05$ maka dapat diambil kesimpulan bahwa terdapat perbedaan data ratarata kadar kolesterol darah pada hari ke-0 dan hari ke-14 pada kelompok tikus hiperkolesterol dengan pemberian ekstrak daun binahong $1000 \mathrm{mg} / \mathrm{kgBB}$.

Untuk mengetahui apakah ada perbedaan yang signifikan antara data rata-rata kadar kolesterol pada hari ke-0 dengan hari ke-14 pada kelompok tikus hiperkolesterol dengan pemberian ekstrak daun binahong $1500 \mathrm{mg} / \mathrm{kgBB}$, maka dilakukan uji normalitas dengan menggunakan Shapiro-wilk. Dari uji tersebut sebaran data rata-rata kadar kolesterol total darah hari ke-0, nilai $\mathrm{p}=0,962$ dan hari ke-14, nilai $\mathrm{p}=0,116$; data berdistribusi normal dengan $\mathrm{p}>0,05$. Oleh karena data penelitian pada kelompok tikus hiperkolesterol dengan pemberian ekstrak daun binahong 1500 $\mathrm{mg} / \mathrm{kgBB}$ berdistribusi normal maka untuk menganalisis adanya perbedaan data rata-rata kadar kolesterol darah pada hari ke-0 dan hari ke14 dilakukan uji $t$-test berpasangan. Dari hasil uji $\mathrm{T}$ berpasangan didapatkan hasil nilai $\mathrm{p}=0,143$, oleh karena nilai $\mathrm{p}>0,05$, maka dapat diambil kesimpulan bahwa tidak terdapat perbedaan data rata-rata kadar kolesterol darah pada hari ke-0 dan hari ke-14 pada kelompok tikus hiperkolesterol dengan pemberian ekstrak daun binahong 1500 $\mathrm{mg} / \mathrm{kgBB}$.

Untuk mengetahui apakah ada perbedaan yang signifikan data rata-rata kadar kolesterol pada hari ke-0 antar kelompok maka digunakan uji statistik.

Untuk mengetahui adanya perbedaan data ratarata kadar kolesterol antara kelompok 1 dengan kolompok 2 pada hari ke-0, maka dilakukan uji statistik dengan menggunakan t-test tidak berpasangan. Hasil uji statistik diperoleh nilai $\mathrm{p}=$ 0,872 , oleh karena nilai $\mathrm{p}>0,05$ maka dapat diambil kesimpulan bahwa tidak ada perbedaan data rata-rata kadar kolesterol darah pada hari ke-0 antara kelompok 1 dan kelompok 2.

Untuk mengetahui adanya perbedaan data ratarata kadar kolesterol antara kelompok 1 dan 3 pada hari ke-0, maka dilakukan uji statistik menggunakan $t$-test tidak berpasangan. Hasil uji statistik diperoleh nilai $p=0,466$, oleh karena nilai p > 0,05 maka dapat di ambil kesimpulan bahwa tidak ada perbedaan yang signifikan data rata-rata kadar kolesterol darah pada hari ke-0 antara kelompok 1 dan kelompok 3.

Untuk mengetahui adanya perbedaan data ratarata kadar kolesterol antara kelompok 1 dan 4 pada hari ke-0, maka dilakukan uji statistik menggunakan uji T tidak berpasangan. Hasil uji statistik menunjukkan

nilai $p=0,116$, oleh karena nilai $p>0,05$ maka dapat diambil kesimpulan bahwa tidak ada perbedaan yang signifikan data rata-rata kadar kolesterol darah pada hari ke-0 antara kelompok 1 dan kelompok 4.

Untuk mengetahui adanya perbedaan data ratarata kadar kolesterol antara kelompok 2 dan 3 pada hari ke-0, maka dilakukan uji statistik menggunakan uji $\mathrm{T}$ tidak berpasangan. Hasil uji statistik menunjukkan nilai $\mathrm{p}=0,459$, oleh karena p > 0,05 maka dapat diambil kesimpulan bahwa tidak ada perbedaan yang signifikan data rata-rata kadar kolesterol darah pada hari ke-0 antara kelompok 2 dan kelompok 3.

Untuk mengetahui adanya perbedaan data ratarata kadar kolesterol antara kelompok 2 dan 4 pada hari ke-0, maka dilakukan uji statistik 
menggunakan uji $\mathrm{T}$ tidak berpasangan. Hasil uji statistik menunjukkan nilai $p=0,139$, oleh karena p > 0,05 maka dapat diambil kesimpulan bahwa tidak ada perbedaan yang signifikan data rata-rata kadar kolesterol darah pada hari ke-0 antara kelompok 2 dan kelompok 4.

Untuk mengetahui adanya perbedaan data ratarata kadar kolesterol antara kelompok 3 dan 4 pada hari ke-0, maka dilakukan uji statistik menggunakan uji $\mathrm{T}$ tidak berpasangan. Hasil uji statistik menunjukkan nilai $p=0,185$, oleh karena p > 0,05 maka dapat diambil kesimpulan bahwa tidak ada perbedaan yang signifikan data rata-rata kadar kolesterol darah pada hari ke-0 antara kelompok 3 dan kelompok 4.

Untuk mengetahui apakah ada perbedaan yang signifikan data rata-rata kadar kolesterol pada hari ke-14 antar kelompok maka digunakan uji statistik.

Untuk mengetahui adanya perbedaan data ratarata kadar kolesterol antara kelompok 1 dengan kolompok 2 pada hari ke-14, maka dilakukan uji statistik dengan menggunakan t-test tidak berpasangan. Hasil uji statistik diperoleh nilai $\mathrm{p}=$ 0,031 , oleh karena nilai $p<0,05$ maka dapat diambil kesimpulan bahwa ada perbedaan data rata-rata kadar kolesterol darah pada hari ke-14 antara kelompok 1 dan kelompok 2.

Untuk mengetahui adanya perbedaan data ratarata kadar kolesterol antara kelompok 1 dan 3 pada hari ke-14, maka dilakukan uji statistik menggunakan $t$-test tidak berpasangan. Hasil uji statistik diperoleh nilai $p=0,154$, oleh karena nilai p > 0,05 maka dapat di ambil kesimpulan bahwa tidak ada perbedaan yang signifikan data rata-rata kadar kolesterol darah pada hari ke-14 antara kelompok 1 dan kelompok 3.

Untuk mengetahui adanya perbedaan data ratarata kadar kolesterol antara kelompok 1 dan 4 pada hari ke-14, maka dilakukan uji statistik menggunakan uji $\mathrm{T}$ tidak berpasangan. Hasil uji statistik menunjukkan nilai $\mathrm{p}=0,127$, oleh karena nilai $\mathrm{p}>0,05$ maka dapat diambil kesimpulan bahwa tidak ada perbedaan yang signifikan data rata-rata kadar kolesterol darah pada hari ke-14 antara kelompok 1 dan kelompok 4.

Untuk mengetahui adanya perbedaan data ratarata kadar kolesterol antara kelompok 2 dan 3 pada hari ke-14, maka dilakukan uji statistik menggunakan uji Mann Whitney. Hasil uji statistik menunjukkan nilai $p=0,454$, oleh karena $p>0,05$ maka dapat diambil kesimpulan bahwa tidak ada perbedaan yang signifikan data rata-rata kadar kolesterol darah pada hari ke-14 antara kelompok 2 dan kelompok 3 .
Untuk mengetahui adanya perbedaan data rata-rata kadar kolesterol antara kelompok 2 dan 4 pada hari ke-14, maka dilakukan uji statistik menggunakan uji Mann Whitney. Hasil uji statistik menunjukkan nilai $\mathrm{p}=0,803$, oleh karena $\mathrm{p}>0,05$ maka dapat diambil kesimpulan bahwa tidak ada perbedaan yang signifikan data rata-rata kadar kolesterol darah pada hari ke-14 antara kelompok 2 dan kelompok 4.

Untuk mengetahui adanya perbedaan data ratarata kadar kolesterol antara kelompok 3 dan 4 pada hari ke-14, maka dilakukan uji statistik menggunakan uji $\mathrm{T}$ tidak berpasangan. Hasil uji statistik menunjukkan nilai $\mathrm{p}=0,634$, oleh karena p > 0,05 maka dapat diambil kesimpulan bahwa tidak ada perbedaan yang signifikan data rata-rata kadar kolesterol darah pada hari ke-14 antara kelompok 3 dan kelompok 4.

\section{Pembahasan}

Tanaman binahong mengandung banyak senyawa kimia yang berkhasiat, seperti flavonoid dan saponin..$^{15,16}$ Senyawa flavonoid dan saponin bersifat polar, sehingga untuk menariknya dari bagian tanaman, diperlukan larutan yang juga bersifat polar seperti etanol. Senyawa aktif flavonoid memiliki banyak manfaat bagi tubuh. Flavonoid dapat digunakan untuk menurunkan kadar kolesterol total darah. Senyawa tersebut mempunyai kemampuan untuk mengikis endapan kolesterol pada dinding pembuluh darah. Pada flavonoid terdapat kandungan keamperol, di mana peran kaemperol dapat sebagai hipolipidemik dan antioksidan yang bekerja dengan cara meningkatkan aktivasi reseptor kolesterol-LDL, sehingga kolesterol-LDL di dalam darah menjadi turun. Kaemperol mempunyai efek menurunkan kadar kolesterol total, trigliserida, dan kadar kolesterol-LDL plasma pada tikus dengan obesitas dan tinggi kolesterol. Dengan demikian kaemperol bisa bermanfaat bagi pasien hiperkolesterolemia. ${ }^{17}$ Flavonoid memiliki efek antioksidan dan banyak digunakan sebagai salah satu komponen pembentuk obat serta flavonoid memiliki efek lainnya seperti antitumor, analgesik, antiradang, antifugal, antihepatoksik, antidiare dan memiliki efek vasodilator. ${ }^{9,18}$ Senyawa saponin bekerja dengan cara berikatan dengan asam empedu dan membentuk large mixed-micelle, sehingga kolesterol yang berada dalam misel tidak bisa diabsorbsi oleh mikrovilli pada permukaan sel epitel usus, akibatnya kadar kolesterol-LDL dan kolesterol darah total pun akan mengalami penurunan di dalam darah. ${ }^{17}$ 
Data hasil penelitian disajikan dalam bentuk grafik untuk melihat adanya penurunan kadar kolesterol darah pada setiap kelompok. Tikus dinyatakan hiperkolesterol bila kadar kolesterol tikus di dalam darah $>54 \mathrm{mg} / \mathrm{dl} .{ }^{13}$ Pada kelompok 1, tikus hiperkolesterol tidak diberikan perlakuan dan hanya diberikan pakan standar. Pakan standar mengandung protein, serat dan abu, pakan tersebut diberikan kepada kelompok 1,2,3 dan 4 selama penelitian.

Tabel 1. Hasil Uji Statistik Data Rata-Rata Kadar Kolesterol Hari ke-0 dan Hari ke-14 pada Tiap Kelompok

\section{N Rerata \pm SD}

p

Uji t Berpasangan Kelompok 1

Kadar Kolesterol Hari ke-0

$6 \quad 261 \pm 85,1$

0,697

Kadar Kolesterol Hari ke-14

$6 \quad 234 \pm 120,4$

Uji Wilcoxon Kelompok 2

Kadar Kolesterol Hari ke-0

Kadar Kolesterol Hari ke-14

$\begin{array}{cc}6 & 271 \pm 111,8 \\ 6 & 135 \pm 48,3\end{array}$

0,028

Uji t Berpasangan Kelompok 3

$\begin{array}{llll}\text { Kadar Kolesterol Hari ke-0 } & 5 & 231 \pm 26,8 & 0,034 \\ \text { Kadar Kolesterol Hari ke-14 } & 5 & 149 \pm 41,9 & \end{array}$

Uji t Berpasangan Kelompok 4

\begin{tabular}{llll} 
Kadar Kolesterol Hari ke- 0 & 6 & $185,67 \pm 65,01$ & 0,143 \\
Kadar Kolesterol Hari ke-14 & 6 & $142,67 \pm 35,06$ & \\
\hline
\end{tabular}

Pada kelompok 1 terdapat sedikit perbedaan data rata-rata kadar kolesterol hari ke-0 dan hari ke-14 dengan selisih sebesar $27 \mathrm{mg} / \mathrm{dl}$. Hal ini menunjukkan bahwa terjadi sedikit penurunan kadar kolestrol pada hari ke-14, namun penurunan kadar kolesterol tersebut secara statistik tidak signifikan, karena dari hasil uji statistik diketahui bahwa tidak terdapat perbedaan yang signifikan antara kadar kolesterol hari ke-0 dan hari ke-14, dengan nilai $\mathrm{p}=0,697$. Hal ini dimungkinkan karena kelompok tikus hiperkolesterol ini tidak diberi perlakuan sama sekali untuk mengatasi tingginya kolesterol. Penurunan dari kolesterol yang tidak signifikan ini mungkin saja terjadi karena di dalam metabolismenya kolesterol secara fisiologis akan dapat diubah menjadi asam dan garam empedu yang dipakai untuk proses pencernaan lemak. ${ }^{19}$

Pada kelompok tikus hiperkolesterol yang diberikan perlakuan dengan obat simvastatin, terdapat perbedaan data rata-rata kadar kolesterol pada hari ke-0 dan hari ke-14, selisih sebesar 136 $\mathrm{mg} / \mathrm{dl}$. Obat simvastatin merupakan obat kolesterol yang memiliki efek dalam penurunan kadar kolesterol total dan LDL, obat simvastatin bekerja menghambat enzim HydroxymethylglutarylCoenzime A (HMG-CoA) Reductase yang berperan dalam mengubah $H M G-C o A$ menjadi mevalonat. ${ }^{6,20}$ Dari hasil uji statistik diketahui ada perbedaan yang signifikan antara data rata-rata kadar kolesterol hari ke-0 dan hari ke-14, dengan nilai $p=0,028$ yang berarti terdapat penurun kadar kolesterol darah yang signifikan pada kelompok tikus hiperkolesterol yang diberikan perlakuan dengan obat simvastatin.

Pada kelompok tikus hiperkolestrol yang diberikan perlakuan dengan pemberian ekstrak daun binahong sebesar $1000 \mathrm{mg} / \mathrm{kgBB}$ terdapat perbedaan data rata-rata kadar kolesterol pada hari ke-0 dan hari ke-14 dengan selisih sebesar 82 $\mathrm{mg} / \mathrm{dl}$, sementara pada kelompok tikus hiperkolesterol yang diberi perlakuan dengan pemberian ekstrak daun binahong sebesar 1500 $\mathrm{mg} / \mathrm{kgBB}$, terdapat perbedaan data rata-rata kadar kolesterol antara hari ke-0 dan ke-14 sebesar 43 $\mathrm{mg} / \mathrm{dl}$. Ekstrak daun binahong mempunyai senyawa aktif flavonoid yang dapat menurunkan kadar kolesterol total darah dan mempunyai kemampuan untuk mengikis endapan kolesterol pada dinding pembuluh darah. Flavonoid mempunyai zat aktif kaemperol yang berfungsi menurunkan kadar kolesterol total dengan mengaktivasi Peroxisome Proliferator-Activated Receptor $\alpha$ (PPAR $\alpha),{ }^{17}$ yang merupakan faktor transkripsi yang memegang peranan penting dalam berbagai fungsi seluler termasuk metabolisme lemak. ${ }^{19}$

Dari hasil uji statistik terhadap data rata-rata kadar kolesterol pada hari ke-0 dan hari ke-14 diketahui ada perbedaan yang signifikan, dengan nilai $\mathrm{p}=0,034$ yang berarti terdapat penurunan kadar kolesterol darah yang signifikan pada kelompok tikus hiperkolesterol yang diberikan ekstrak daun binahong dosis $1000 \mathrm{mg} / \mathrm{kgBB}$. Sedangkan dari hasil uji statistik terhadap data rata-rata kadar kolesterol pada kelompok pemberian dosis $1500 \mathrm{mg} / \mathrm{kgBB}$ diketahui bahwa tidak ada perbedaan yang signifikan antara data rata-rata kadar kolesterol pada hari ke - 0 dan hari ke-14, dengan nilai $\mathrm{p}=0,143$, yang berarti penurunan yang terjadi pada kelompok 4 ini tidak signifikan secara statistik. Hal ini mungkin karena di dalam ekstrak daun binahong dengan dosis yang tinggi tersebut $(1500 \mathrm{mg} / \mathrm{kgBB})$, terkandung pula senyawa lain yang berefek pada metabolisme kolesterol, sehingga efek flavonoid dalam penurunan kolesterol menjadi terganggu. Perlu 
penelitian lebih lanjut untuk mengetahui senyawasenyawa lain yang terkandung pada ekstrak daun binahong tersebut, serta efek pada metabolisme kolesterol di dalam tubuh.

Tabel 2. Hasil Uji Statistik Data Rata-Rata Kadar Kolesterol Hari ke-0 antar Kelompok

\begin{tabular}{|c|c|c|c|c|}
\hline & Kelompok & $\mathbf{N}$ & Rerata \pm SD & $\mathbf{p}$ \\
\hline \multicolumn{5}{|c|}{ Uji T tidak berpasangan } \\
\hline \multirow[t]{2}{*}{ Kolesterol } & Kelompok 2 & 6 & $271 \pm 111,8$ & 0,872 \\
\hline & Kelompok 1 & 6 & $261 \pm 85,1$ & \\
\hline \multicolumn{5}{|c|}{ Uji T tidak berpasangan } \\
\hline \multirow[t]{2}{*}{ Kolesterol } & Kelompok 3 & 5 & $231 \pm 26,8$ & 0,466 \\
\hline & Kelompok 1 & 6 & $261 \pm 85,1$ & \\
\hline \multicolumn{5}{|c|}{ Uji Ttidak berpasangan } \\
\hline \multirow[t]{2}{*}{ Kolesterol } & Kelompok 4 & 6 & $185,67 \pm 65,01$ & 0,116 \\
\hline & Kelompok 1 & 6 & $261 \pm 85,1$ & \\
\hline \multicolumn{5}{|c|}{ Uji T tidak berpasangan } \\
\hline \multirow[t]{2}{*}{ Kolesterol } & Kelompok 3 & 5 & $231 \pm 26,8$ & 0,459 \\
\hline & Kelompok 2 & 6 & $271 \pm 111,8$ & \\
\hline \multicolumn{5}{|c|}{ Uji T tidak berpasangan } \\
\hline \multirow[t]{2}{*}{ Kolesterol } & Kelompok 4 & 6 & $185,67 \pm 65,01$ & 0,139 \\
\hline & Kelompok 2 & 6 & $271 \pm 111,8$ & \\
\hline \multicolumn{5}{|c|}{ Uji T tidak berpasangan } \\
\hline \multirow[t]{2}{*}{ Kolesterol } & Kelompok 4 & 6 & $185,67 \pm 65,01$ & 0,185 \\
\hline & Kelompok 3 & 5 & $231 \pm 26,8$ & \\
\hline
\end{tabular}

Dari hasil uji statistik terhadap data rata-rata kadar kolesterol kelompok tikus hiperkolesterol tanpa perlakuan, kelompok tikus hiperkolesterol dengan pemberian obat simvastatin, kelompok tikus hiperkolesterol dengan pemberian ekstrak daun binahong dosis $1000 \mathrm{mg} / \mathrm{kgBB}$, dan kelompok tikus hiperkolesterol dengan pemberian ekstrak daun binahong dosis $1500 \mathrm{mg} / \mathrm{kgBB}$ pada hari ke-0, diketahui semua data rata-rata kadar kolesterol antar kelompok menunjukkan nilai $\mathrm{p}>$ 0,05 , artinya data rata-rata kadar kolesterol pada setiap kelompok diawali dengan kadar kolesterol yang tidak berbeda secara signifikan.

Pada Gambar 2 menunjukkan penurunan data rata-rata kadar kolesterol lebih baik pada kelompok tikus hiperkolesterol dengan pemberian obat simvastatin (sebesar $136 \mathrm{mg} / \mathrm{dl}$ ) dibandingkan kelompok tikus hiperkolesterol tanpa perlakuan (sebesar $27 \mathrm{mg} / \mathrm{dl}$ ), dikarenakan kelompok 2 diterapi dengan obat sedangkan kelompok 1 tidak diberi perlakuan. Hasil uji statistik dengan menggunakan $t$-test tidak berpasangan terhadap data rata-rata kadar kolesterol pada hari ke-14 antara kelompok 1 dan kelompok 2, diperoleh nilai $\mathrm{p}=0,031$. Oleh karena nilai $\mathrm{p}<0,05$, maka dapat diambil kesimpulan bahwa terdapat perbedaan yang signifikan antara data rata-rata kadar kolesterol darah pada hari ke-14 antara kelompok 1 dan kelompok 2. Hal ini disebabkan karena kelompok tikus hiperkolesterol, diberi perlakuan obat simvastatin (obat standar penurun kolesterol) sedangkan kelompok tikus hiperkolesterol tidak diberikan penurun kadar kolesterol.

Pada Gambar 2 dapat dilihat bahwa kelompok tikus hiperkolesterol tanpa perlakuan dibandingkan dengan kelompok tikus hiperkolesterol dengan pemberian ekstrak daun binahong dosis $1000 \mathrm{mg} / \mathrm{kgBB}$ menunjukkan penurunan data rata-rata kadar kolesterol lebih baik pada kelompok 3 (sebesar $82 \mathrm{mg} / \mathrm{dl}$ ) dibandingkan kelompok 1 (sebesar $27 \mathrm{mg} / \mathrm{dl}$ ). Hal ini membuktikan bahwa ekstrak daun binahong dosis $1000 \mathrm{mg} / \mathrm{kgBB}$ memberikan efek menurunkan kadar kolesterol darah.

Dari hasil uji statistik dengan menggunakan $t-$ test tidak berpasangan terhadap data rata-rata kadar kolesterol pada hari ke-14 antara kelompok 1 dan kelompok 3, diperoleh nilai $\mathrm{p}=0,154$. Dapat di ambil kesimpulan bahwa tidak ada perbedaan yang signifikan data rata-rata kadar kolesterol darah pada hari ke-14 antara kelompok 1 dan kelompok 3. Data rata-rata kadar kolesterol hari ke-14 pada kelompok 1 sebesar $234 \mathrm{mg} / \mathrm{dl}$, sementara pada kelompok 3 sebesar $149 \mathrm{mg} / \mathrm{dl}$ tidak terlalu berbeda. Meskipun demikian dari hasil uji statistik, diketahui terjadi penurunan data rata-rata kadar kolesterol secara signifikan pada kelompok tikus hiperkolesterol yang diberikan ekstrak daun binahong $1000 \mathrm{mg} / \mathrm{kgBB}$, sementara penurunan data rata-rata kadar kolesterol pada kelompok 1 tidak terjadi secara signifikan.

Pada Gambar 2 dapat dilihat bahwa kelompok tikus hiperkolesterol tanpa perlakuan dibandingkan dengan kelompok tikus hiperkolesterol dengan pemberian ekstrak daun binahong dosis $1500 \mathrm{mg} / \mathrm{kgBB}$ menunjukkan penurunan data rata-rata kadar kolesterol lebih baik pada kelompok $4 \quad(43 \mathrm{mg} / \mathrm{dl})$ dibandingkan kelompok 1 (27 mg/dl). Hal ini membuktikan bahwa ekstrak daun binahong dosis $1500 \mathrm{mg} / \mathrm{kgBB}$ memberikan efek menurunkan kadar kolesterol darah, meskipun efeknya kecil dan secara statistik tidak signifikan.

Dari hasil uji statistik $t$-test tidak berpasangan terhadap data rata-rata kadar kolesterol pada hari ke-14 antara kelompok 1 dan kelompok 4 diperoleh nilai $\mathrm{p}=0,127$ dan dapat diambil kesimpulan bahwa tidak ada perbedaan yang signifikan data rata-rata kadar kolesterol darah pada hari ke-14 antara kelompok 1 dan kelompok 
4. Data rata-rata kadar kolesterol hari ke-14 pada kelompok 1 (sebesar $234 \mathrm{mg} / \mathrm{dl}$ ), sementara pada kelompok 4 (sebesar $143 \mathrm{mg} / \mathrm{dl}$ ) tidak berbeda signifikan secara statistik. Meskipun demikian bila dilihat dari Gambar 2, terjadi penurunan data ratarata kadar kolesterol pada kelompok tikus hiperkolesterol yang diberikan ekstrak daun binahong $1500 \mathrm{mg} / \mathrm{kgBB}$ yang lebih besar dari penurunan data rata-rata kadar kolesterol pada kelompok tikus hiperkolesterol tanpa perlakuan.

Tabel 3. Hasil Uji Statistik Data Rata-Rata Kadar Kolesterol Hari ke-14 antar Kelompok

\begin{tabular}{|c|c|c|c|c|}
\hline & Kelompok & $\mathbf{N}$ & Rerata \pm SD & p \\
\hline \multicolumn{5}{|c|}{ Uji T tidak berpasangan } \\
\hline \multirow[t]{2}{*}{ Kolesterol } & Kelompok 2 & 6 & $135 \pm 48,3$ & 0,031 \\
\hline & Kelompok 1 & 6 & $234 \pm 120,4$ & \\
\hline \multicolumn{5}{|c|}{ Uji T tidak berpasangan } \\
\hline \multirow[t]{2}{*}{ Kolesterol } & Kelompok 3 & 5 & $149 \pm 41,9$ & 0,154 \\
\hline & Kelompok 1 & 6 & $234 \pm 120,4$ & \\
\hline \multicolumn{5}{|c|}{ Uji T tidak berpasangan } \\
\hline \multirow[t]{2}{*}{ Kolesterol } & Kelompok 4 & 6 & $142.67 \pm 35,06$ & 0,127 \\
\hline & Kelompok 1 & 6 & $234 \pm 120,4$ & \\
\hline \multicolumn{5}{|c|}{ Uji Mann Whitney } \\
\hline \multirow[t]{2}{*}{ Kolesterol } & Kelompok 3 & 5 & $149 \pm 41,9$ & 0,454 \\
\hline & Kelompok 2 & 6 & $135 \pm 48,3$ & \\
\hline \multicolumn{5}{|c|}{ Uji Mann Whitney } \\
\hline \multirow[t]{2}{*}{ Kolesterol } & Kelompok 4 & 6 & $142,67 \pm 35,06$ & 0,803 \\
\hline & Kelompok 2 & 6 & $135 \pm 48,3$ & \\
\hline \multicolumn{5}{|c|}{ Uji T tidak berpasangan } \\
\hline \multirow[t]{2}{*}{ Kolesterol } & Kelompok 4 & 6 & $142.67 \pm 35,06$ & 0,804 \\
\hline & Kelompok 3 & 5 & $149 \pm 41,9$ & \\
\hline
\end{tabular}

Pada Gambar 2 menunjukkan kelompok tikus hiperkolesterol dengan terapi obat simvastatin, kelompok tikus hiperkolesterol dengan terapi ekstrak daun binahong $1000 \mathrm{mg} / \mathrm{kgBB}$, dan kelompok tikus hiperkolesterol dengan ekstrak daun binahong $1500 \mathrm{mg} / \mathrm{kgBB}$, memperlihatkan bahwa kelompok 2 terjadi penurunan kadar kolesterol yang lebih baik dibandingkan kelompok 3 dan kelompok 4, dikarenakan kelompok 2 menggunakan obat simvastatin yang merupakan obat standar dalam penurunan kadar kolesterol, sedangkan ekstrak daun binahong mempunyai efek juga dalam menurunkan kadar kolestrol akan tetapi tidak begitu besar bila dibandingkan dengan simvastatin.

Secara keseluruhan penelitian menunjukan bahwa pemberian ekstrak daun binahong 1000 $\mathrm{mg} / \mathrm{kgBB}$ dan $1500 \mathrm{mg} / \mathrm{kgBB}$ dapat menurunkan kadar kolesterol darah tikus pada hari ke-14, meskipun secara statistik penurunan kadar kolesterol signifikan hanya pada kelompok pemberian ekstrak daun binahong $1000 \mathrm{mg} / \mathrm{kgBB}$. Hal ini karena di dalam ekstrak daun binahong mengandung flavonoid yang dapat mempengaruhi penurunan kadar kolestrol., ${ }^{7,21}$ Flavonoid mempunyai kandungan kaemperol, di mana peranan dari kaemperol dapat sebagai hipolipidemik dan antioksidan yang bekerja dengan cara meningkatkan aktivitas resepetor kolesterol-LDL sehingga kolesterol-LDL di dalam darah menjadi turun dan mempunyai efek menurunkan trigliserida, serta kolesterol total. ${ }^{17}$

Jika dibandingkan antara efek ekstrak daun binahong $1000 \mathrm{mg} / \mathrm{kgBB}$ dan $1500 \mathrm{mg} / \mathrm{kgBB}$ dengan simvastatin terhadap penurunan kadar kolesterol darah, efek simvastatin lebih baik dikarenakan simvastatin merupakan obat standar yang digunakan untuk menurunkan kadar kolesterol dengan menghambat enzim $\mathrm{HMG}-\mathrm{COA}$ Reduktase. Enzim tersebut berperan dalam mengubah HMG-COA menjadi mevalonate. ${ }^{6,13}$

Hasil penelitian terhadap kadar kolesterol darah total ini dapat mendukung penelitian sebelumnya yang dilakukan oleh Aprilia dan Dewiastuti pada tahun 2017, menyatakan bahwa ekstrak binahong yang berpengaruh secara signifikan dalam menurunkan kadar kolesterol LDL darah tikus adalah dosis $1000 \mathrm{mg} / \mathrm{kgBB}$ dibandingkan dosis ekstrak daun binahong 1500 $\mathrm{mg} / \mathrm{kgBB}$. Namun masih diperlukan penelitian lebih lanjut untuk memeriksa komposisi dan mekanisme kerja senyawa-senyawa yang terdapat pada ekstrak binahong tersebut. ${ }^{17}$

\section{Simpulan}

Dari hasil penelitian memperlihatkan ekstrak daun binahong dengan dosis $1000 \mathrm{mg} / \mathrm{kgBB}$ dan $1500 \mathrm{mg} / \mathrm{kgBB}$ dapat menurunkan kadar kolesterol darah total. Secara statistik pemberian ekstrak daun binahong dengan dosis $1000 \mathrm{mg} / \mathrm{kgBB}$ menunjukkan penurunan kadar kolesterol darah total secara signifikan. Bila dibandingkan dengan simvastatin masih lebih baik efek simvastatin dalam menurunkan kadar kolesterol darah total, dibandingkan dengan ekstrak daun binahong.

\section{Daftar Pustaka}

1. World Health Organization (WHO). Cardiovascular diseases. 2020. Available from : $\quad$ https://www.euro.who.int/en/healthtopics/noncommunicable- 
diseases/cardiovascular-diseases Diakses tanggal 24 Agustus 2021.

2. Badan Penelitian dan Pengembangan Kesehatan (Badan Litbangkes). Riset kesehatan dasar. Jakarta : Kementrian Kesehatan Republik Indonesia. 2013.

3. Badan Penelitian dan Pengembangan Kesehatan (Badan Litbangkes). Riset kesehatan dasar. Jakarta: Kementrian Kesehatan Republik Indonesia. 2018.

4. Purnamasari D. Diagnosis dan klasifikasi diabetes mellitus. Dalam: Setiati S, Alwi I, Sudoyo AW, Setiyohadi B, Simadibrata MS, Syam AF. Buku ajar ilmu penyakit dalam . Edisi IV. Jilid II. Jakarta : Interna Publishing; 2014.h.1427.

5. American Heart Association. Heart-health screenings. What is cardiovascular disease. Jun;2017.

6. Gunawan SG, Setiabudy R, Nafrialdi, Elysabeth. Famakologi dan terapi. Edisi 5. Jakarta: Departemen Farmakologi dan Terapeutik Fakultas Kedokteran Universitas Indonesia; 2007.h.386-95.

7. Larissa U, Wulan AJ, Prabowo AY. Pengaruh binahong terhadap luka bakar derajat II. Jurnal Majority. 2017;7(1):130-4.

8. Mardini U. Pengaruh kombinasi 2,4-d dan bap terhadap induksi kalus eksplan daun dan batang tanaman binahong (Anredera cordifolia (Ten.) steenis) secara in vitro. Program Studi Pendidikan Biologi [Skripsi]. Fakultas Keguruan dan Ilmu Pendidikan. Surakarta: Universitas Muhammadiyah; 2015.

9. Khunaifi M. Uji aktivitas antibakteri ekstrak daun binaahong (Anredera cordifolia (Ten.) steenis) terhadap bakteri Staphylococcus aureus dan Pseudomonas aeruginosa. Program Studi Biologi. Fakultas Sains dan Teknologi. Universitas Islam Negeri Maulana Malik Ibrahim Malang. 2010.

10. Pariyana, Saleh MR., Tjekyan S, Hermansyah Efektivitas pemberian ekstrak daun binahong (Anredera Cordifolia) terhadap ketebalan jaringan granulasi dan jarak tepi luka pada penyembuhan sayat tikus putih (Rattus Norvegicus). Jurnal Kedokteran dan Kesehatan. 2016;3(3):155-65.

11. Pebri I, Rinidar, Amiruddin. Pengaruh pemberian ekstrak daun binahong (Anredera cordifolia) terhadap proses penyembuhan luka insisi (Vulnus incisivum) pada mencit (Mus musculus). Jurnal Ilmiah Mahasiswa Veteriner. 2017;2(1):1-11.
12. Fitriyah N, Purwa M, Alfiyanto MA, Mulyadi, Wahuningsih N, Kismanto J. Obat herbal antibakteri ala tanaman binahong. Jurnal Kesehatan Kusuma Husada. 2013:116-22.

13. Harini M, Astirin OP. Blood cholesterol levels of hypercholesterolemic rat (Rattus norvegicus) after VCO treatment. Nusantara Bioscience. 2009;1:53-8.

14. Umami SR, Hapizah SS, Fitri R, Hakim A. Uji penurunan kolesterol pada mencit putih (Mus musculus) secara in-vivo menggunakan ekstrak metanol umbi talas (Colocasia esculenta L) sebagai upaya pencegahan cardiovascular disease. Universitas Mataram. Jurnal Pijar MIPA. 2016; IX(2):121-4.

15. Etha, Hasiib A, Riyanti, Hartono M. Pengaruh pemberian ekstrak daun binahong (Anredera cordifolia (Ten.) Steenis) dalam air minum terhadap performa broiler. Universitas Lampung. Jurnal Ilmiah Peternakan Terpadu. 2015;3(1):14-22.

16. Darsana, Mahatmi. Potensi daun binahong (Anredera Cordifolia (Tenore) Steenis) dalam menghambat pertumbuhan bakteri Escherichia Coli secara in vitro. Indonesia Medicus Veterinus. 2012;1(3):346.

17. Aprilia CA, Dewiastuti M. Efektivitas hipolipidemia dan antioksidan ekstrak daun binahong pada tikus putih yang diinduksi pakan hiperkolesterol. Universitas Pembangunan Nasional veteran Jakarta. Jurnal Kedokteran Yarsi. 2017;25(3):150-62.

18. Anggraini DI, Ali MM. Uji aktivitas antikolesterol ekstrak etanol daun binahong (Anredera cordifolia (Ten) Steenis) secara invitro. Sekolah Tinggi Ilmu kesehatan Surakarta. Jurnal Ilmiah Kesehatan. 2017;9(1):1-6.

19. Murray RK, Bender DA, Botman KM, Kennelly PJ, Rodwell VW, Weil PA. Biokimia harper. Edisi 29. Jakarta: Penerbit EGC; 2014.

20. Anggraini DY. Pengaruh penggunan leaflet sebagai media pendidikan kesehatan terhadap kepatuhan terapi dan penurunan kadar kolesterol pasien hiperkolesterolemia di Puskesmas Tegalrejo Yogyakarta. Karya Tulis Ilmiah. Yogyakarta: Program Studi Farmasi.Universitas Muhammadiyah; 2015.

21. Hasbullah UHA. Kandungan senyawa saponin pada daun, batang dan umbi tanaman binahong (Anredera cordifolia (Ten) Steenis). Universitas PGRI Semarang. Planta Tropika Journal of Agro Science. 2016;4(1):20-4. 